\title{
In-Use Performance Comparison of Hybrid Electric, CNG, and Diesel Buses at New York City Transit
}

\author{
Robb A. Barnitt \\ National Renewable Energy Laboratory - U.S. Department of Energy
}

Copyright @ 2008 SAE International

\section{ABSTRACT}

The National Renewable Energy Laboratory (NREL) evaluated the performance of diesel, compressed natural gas (CNG), and hybrid electric (equipped with BAE Systems' HybriDrive propulsion system) transit buses at New York City Transit (NYCT). CNG, Gen I and Gen II hybrid electric propulsion systems were compared on fuel economy, maintenance and operating costs per mile, and reliability. These comparisons are based upon comparable service years; the second year in service for CNG and Gen II hybrids, and the second and third years in service for the Gen I hybrids. Conventional diesel buses provided a baseline comparison for fuel economy. Both the CNG and hybrid propulsion systems are alternatives to standard diesel buses and allow for reductions in petroleum use and emissions (usually focused on reductions of particulate matter and oxides of nitrogen).

The Gen I hybrid buses exhibited $88 \%$ and $37 \%$ higher fuel economy than CNG and conventional diesel buses, respectively. The average fuel economy for the Gen II hybrid buses was $5.9 \%$ lower than the Gen I hybrid buses. Fuel economy decreased for all bus groups during summer operation due to air conditioning load. However, the hybrids exhibited the most dramatic seasonal fluctuation.

The average total maintenance cost per mile for the Gen II hybrid buses was 39\% lower than the Gen I hybrid buses, while the CNG buses' average was 5\% higher than the Gen I hybrid buses. Total propulsion-related systems maintenance costs per mile were $55 \%$ lower for the Gen II hybrid buses than the Gen I hybrid buses, while the CNG buses were $5 \%$ lower than the Gen I hybrid buses.

The Gen I hybrids experienced a $4.8 \%$ traction battery failure rate per year during evaluation year 1 , and a $3.3 \%$ failure rate per year during evaluation year 2 . BAE Systems utilizes lead-acid chemistry Hawker batteries.

Hybrid buses are expected to have reduced brake reline frequency because they use regenerative braking. The Gen I hybrid buses accumulated more than two times the mileage of the CNG buses before requiring their first brake reline.

\section{INTRODUCTION}

The U.S. transit market, including NYCT, has been under public and EPA pressure to reduce emissions from large transit buses-especially those in urban areas (see Table 1).

Table 1: EPA Emissions Requirements For Transit Buses

\begin{tabular}{|c|c|c|c|c|}
\hline \multirow{2}{*}{$\begin{array}{l}\text { Model } \\
\text { Years }\end{array}$} & $\mathrm{CO}$ & $\mathrm{HC}$ & NOx & PM \\
\hline & $\begin{array}{c}\text { g/bhp- } \\
\mathrm{hr}\end{array}$ & $\begin{array}{c}\text { g/bhp- } \\
\text { hr }\end{array}$ & g/bhp-hr & $\begin{array}{c}\text { g/bhp- } \\
\mathrm{hr}\end{array}$ \\
\hline 1990 & 15.5 & 1.3 & 6.0 & 0.60 \\
\hline 1991-1992 & 15.5 & 1.3 & 5.0 & 0.25 \\
\hline 1993 & 15.5 & 1.3 & 5.0 & 0.10 \\
\hline 1994-1995 & 15.5 & 1.3 & 5.0 & 0.07 \\
\hline 1996-1997 & 15.5 & 1.3 & 5.0 & 0.05 \\
\hline 1998-2003 & 15.5 & 1.3 & 4.0 & 0.05 \\
\hline $2004-2006$ & 15.5 & \multicolumn{2}{|c|}{$\begin{array}{c}2.4 \text { combined or } \\
2.5 \text { with a limit of } \\
0.5 \text { for NMHC }\end{array}$} & 0.05 \\
\hline $2007-2010$ & 15.5 & 0.14 & 0.2 & 0.01 \\
\hline
\end{tabular}

Conventional diesel bus propulsion technology has made emissions reduction improvements and is required to become even cleaner in the next few years. The emissions of primary concern and subsequent regulation in diesel combustion are oxides of nitrogen (NOx) and particulate matter (PM). NOx levels were reduced from $4.0 \mathrm{~g} / \mathrm{bhp}-\mathrm{hr}$ in 1998 to $2.4 \mathrm{~g} / \mathrm{bhp}-\mathrm{hr}$ combined NOx and $\mathrm{HC}$ in 2004 (CNG levels are $2.5 \mathrm{~g} / \mathrm{bhp}-\mathrm{hr} \mathrm{NMHC}+\mathrm{NOx}$ with a limit of $0.5 \mathrm{~g} / \mathrm{bhp}-\mathrm{hr} \mathrm{NMHC}$ ). The 2004 level was applied in 2002 based upon an agreement between EPA and diesel engine manufacturers. The emissions reduction requirement of $2.4 \mathrm{~g} / \mathrm{bhp}-\mathrm{hr} \mathrm{HC}+\mathrm{NOx}$ caused several diesel engine manufacturers to use EGR to help reduce NOx levels. The use of EGR has some effect on durability and fuel economy compared to non-EGR engines. PM levels have been restricted to a low level of $0.05 \mathrm{~g} / \mathrm{bhp}-\mathrm{hr}$ since 1996 and have been regulated even lower in 2007 . These PM regulations effectively require 
the use of diesel particulate filters (DPF) and require ultra low sulfur diesel (ULSD) fuel (less than $15 \mathrm{ppm}$ sulfur).

Some transit agencies have taken action ahead of federal regulation, targeting reduced emissions and fuel savings on a basis of public welfare and reduced operating costs. NYCT's Clean Bus Program was created in 1992 to lower bus fleet emissions. In 2000, NYCT established a policy of only purchasing low emission buses for new bus orders. This policy, coupled with NYCT's desire to achieve the best fuel economy, has resulted in several purchase orders of hybrid buses. Historically, the NYCT Clean Bus Program has included these activities:

- Replacement of the oldest diesel engines (twostroke) with newer low emissions engines

- Use of low sulfur diesel fuel for all diesel equipment (starting in 1998 with less than 30 ppm sulfur, and transitioning to $15 \mathrm{ppm}$ ULSD in 2006)

- Addition of DPFs to existing and new diesel buses

- Use of CNG buses

- Use of hybrid electric buses equipped with DPFs.

Hybrid electric technology was tested at NYCT in an effort to explore options other than CNG technology. This is because not all of NYCT's operating depots are costeffective candidates for CNG infrastructure due to space constraints inside buildings and the proximity of neighboring buildings. In early 2000, NYCT ordered 260 CNG buses from Orion Bus Industries. At the same time, NYCT made a commitment to purchase two orders of buses with the BAE Systems hybrid propulsion system from Orion Bus Industries. One order was for 125 buses, the other for 200 buses.

There are few quantitative studies of BAE Systems hybrid electric transit bus in-use performance [1-3]. These studies are of value to transit fleet managers who are considering the purchase of vehicles that incorporate a new technology or utilize an alternative fuel. In-use evaluations of new technology such as this only consider the first few years of operation. A comprehensive life cycle cost analysis is not currently available.

The development of diesel hybrid electric transit bus propulsion systems is exciting for the transit industry because the systems offer potentially improved fuel economy during a time of fuel economy penalties for diesel engines with added emissions control systems. These systems may also offer an alternative to CNG which offer improved emissions over conventional diesels, but suffer from a fuel economy penalty.

\section{OBJECTIVES}

The first objective of this study was to compare hybrid electric transit buses, and those operating on CNG and conventional diesel in terms of fuel economy, vehicle maintenance, reliability, and operating costs. Secondary objectives were to assess traction battery replacement frequency and costs, and quantify the benefits of regenerative braking with hybrid electric buses. The results help NYCT - and other potential hybrid electric- or CNG-powered bus users-understand the costs and benefits of using these alternatives to diesel, and any changes to maintenance and operating procedures that may be required.

\section{APPROACH}

INTRODUCTION - This project was conducted by NREL under the Department of Energy (DOE) sponsored Advanced Vehicle Testing Activity (AVTA). AVTA evaluation projects focus on using a standardized process for data collection and analysis, communicating results clearly, and providing an accurate and complete evaluation. AVTA evaluations focus on data collection and analysis of advanced propulsion systems compared to baseline propulsion systems, and track multiple vehicles within a fleet in order to provide enough data samples to ensure some level of statistical significance. In this case, 10 vehicles of each technology were chosen for data analysis to provide accurate and statistically valuable results. The results from these evaluations are a snapshot of experience and actual capital and operating costs at a given location and for a given period of time. At this time, the AVTA evaluations do not include an attempt at life cycle cost modeling.

PROJECT DESIGN - This report is in effect a compilation of several AVTA evaluations conducted at NYCT. The focus is on hybrid electric transit buses purchased by NYCT in an order group of 200 (Gen II), and their performance during their first year of service. This latest generation exhibits several improvements, which allows an evolutionary comparison to similar hybrid electric transit buses purchased by NYCT in an order group of 125 (Gen I), which have now been in service for more than 3 years. In this case, Gen I buses are considered the baseline, and data from their first year of service are used for performance comparison. In addition, the performance of CNG buses is compared directly to Gen I hybrid electric buses, and extrapolated to Gen II hybrids. These CNG buses were purchased and put in service in concert with Gen I hybrids. Finally, older (1994 and 1999) diesel buses are included for comparison solely on a basis of fuel economy and roadcall rates, NOT maintenance costs. NYCT has not purchased diesel buses (which could be considered baseline) since 1999, thus a full comparison of hybrid electric and CNG as alternatives to diesel baseline is not possible.

NYCT expects the CNG buses to have diesel-like reliability and operating costs. The hybrid buses were expected to be slightly less commercial than the CNG buses due to the lack of industry experience with hybrid propulsion technology. However, NYCT operated the 
hybrid buses with the intent that they be treated like any diesel bus for reliability and operations.

Ten Gen II hybrid buses at the Manhattanville (MTV) Depot were evaluated. These ten Gen II buses (evaluation year 1) are compared to ten Gen I hybrid buses (evaluation years 1 and 2) from Mother Clara Hale (MCH) Depot. Performance was compared to ten CNG buses at the West Farms (WF) Depot (evaluation year 1), and the aggregate of ten diesel buses from $\mathrm{MCH}$ and ten diesel buses from WF. This comparison is appropriate for the following reasons:

- All 40-ft buses at the depots included in this evaluation were dispatched randomly on all routes.

- The overall depot average speeds are comparable:

○ WF 2004-05 (CNG, diesel) $=6.4 \mathrm{mph}$

- $\mathrm{MCH}$ 2004-05 (Gen I hybrid, diesel) = $6.1 \mathrm{mph}$

○ $\mathrm{MCH}$ 2005-06 (Gen I hybrid) $=5.7 \mathrm{mph}$

- MTV 2006-07 (Gen II hybrid) $=6.1 \mathrm{mph}$

- There were no restrictions on the buses at the depots in this evaluation report.

- $\quad$ NYCT operates and maintains its buses with the expectation that they operate and perform to NYCT standards, regardless of power-train type.

The evaluation periods used to compare bus groups considered in this report are:

- Hybrid Gen II (evaluation year 1): February 2006 through January 2007

- Hybrid Gen I (evaluation year 1): October 2004 through September 2005

- Hybrid Gen I (evaluation year 2): October 2005 through September 2006

- CNG: October 2004 through September 2005

- Diesel: June 2004 through May 2005

Each evaluation year represents a 12-month period of operation. Although some data exists outside the ranges noted above, and has been included in trends for better visualization, comparison of the bus groups is restricted to data specific to the evaluation periods cited.

Vehicle-specific data for this evaluation were taken from NYCT's data system: Maintenance Information Diagnostic Analysis System (MIDAS). Data parameters included the following:

- Diesel fuel consumption

- CNG fuel consumption

- Mileage accumulation

- Preventive maintenance action work orders, parts lists, labor records, and related documents

- Records of unscheduled maintenance, including roadcalls (RCs) and warranty actions by vendors (when available in the data system).
Two major interests in hybrid bus operations held by the transit industry are (1) determining traction battery replacement frequency and costs, and (2) quantifying the benefits of regenerative braking. To address these interests, this report also examines the second year of Gen I bus service with respect to traction battery maintenance. In addition, the benefits of regenerative braking, realized in less frequent brake relines and concomitant reduced maintenance costs, are evaluated using data from Gen I hybrids as compared to baseline CNG buses.

VEHICLE SYSTEM DESCRIPTIONS - Ten CNG buses operating at WF Depot were selected from the order of 260 Orion VII low floor, model year 2002 CNG buses. The CNG buses use the DDC Series $50 G$ engine. NYCT did not purchase the optional catalyst for emissions aftertreatment for these buses. Both the DDC Series 50 diesel and DDC Series 50G CNG engines are no longer available for new transit buses. In 2004, DDC discontinued the Series 50 diesel and CNG engine platform. For years, the diesel Series 50 engine was the workhorse of the transit industry. DDC reported to customers that the Series 50 diesel engine platform could not meet the next round of emissions regulations and was being discontinued after limited refinements in the last few years. Thus, the DDC Series $50 \mathrm{G}$ natural gas engine, operated by NYCT is not the newest technology natural gas engine (with fuel and electronic controls) currently available. Newer engines from other manufacturers may have shown better results.

Although WF Depot is intended to be an all-CNG bus operating depot, some diesel buses have been operating there. The number of diesel buses operating at the depot decreased as the newer CNG buses were brought into service. The evaluation in this report used 10 Orion V high floor diesel buses for a limited comparison to the CNG bus evaluation of fuel economy and roadcall rate results. The diesel buses at $\mathrm{MCH}$ Depot are model year 1999 Orion $V$ high floor buses, but from a newer bus order than those at WF Depot. The diesel buses have DDC Series 50 diesel engines retrofitted with a DPF.

NYCT's hybrid buses are built by Orion Bus Industries (a part of DaimlerChrysler Commercial Buses North America) and use the BAE Systems HybriDrive propulsion system (see Figure 1). 


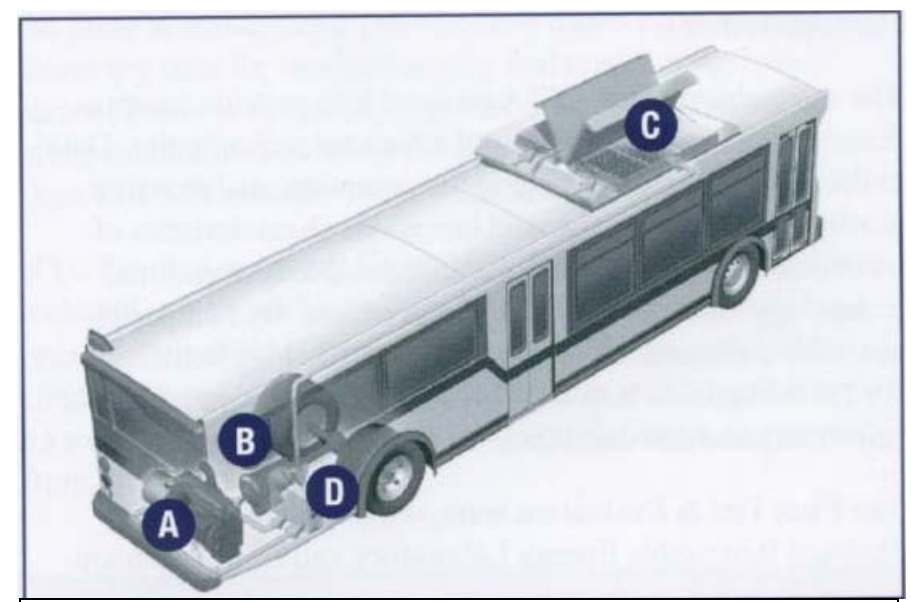

A: A 5.9-L diesel engine runs at an optimal controlled speed and is connected to a generator to produce electrical power for the drive motor and batteries.

B: The electric drive motor drives the vehicle and acts as a generator to capture energy during braking.

C: The batteries supply power during acceleration and hill climbing and store energy recovered during regenerative braking.

D: The propulsion control system manages the entire system and optimizes performance for emissions, fuel economy and power.

Figure 1. BAE Systems HybriDrive Propulsion System

In this series hybrid electric system, a relatively small, downsized Cummins ISB diesel engine running at an optimal controlled speed is connected to a generator that produces electricity for the electric drive motor and batteries. The duty cycle application at NYCT does not allow for steady state operation of the diesel genset. Rather, the engine is operated in power-following mode. Engine loading has been optimized based upon dynamic torque speed characteristics of the engine, provided to BAE by Cummins. The electric drive motor drives the vehicle and acts as a generator to capture energy during regenerative braking. The batteries supply additional power during acceleration and hill climbing and store energy recovered during regenerative braking and idling. The battery optimization subsystem monitors and maintains the charge of each individual battery. Battery State of Charge (SOC) is generally maintained between $70-75 \%$, with some allowance for slightly deeper discharge on highway routes. The propulsion control subsystem manages the entire system and optimizes performance for emissions, fuel economy, and power.
Additional details on the hybrid system are presented in Table 2.

Table 2. Hybrid Propulsion-Related Systems

\begin{tabular}{|ll|}
\hline \multicolumn{1}{c}{ Category } & \multicolumn{1}{c|}{ Hybrid Bus Description } \\
Manufacturer/integrator & BAE Systems (HybriDrive \\
propulsion system) & Type: Alternating current \\
Motor and internal gear & (AC) induction, high-power \\
reduction & density \\
& Horsepower: $250 \mathrm{hp}$ \\
& continuous (320 hp peak) \\
& Torque: 2,700 lb-ft @ 0 rpm \\
Type: Permanent magnet & Horsepower: 160 hp \\
Generator & continuous \\
& Type: Sealed lead-acid, \\
Energy storage & Hawker XT, 2 enclosures, \\
& 23 modules each, roof \\
& mounted \\
& Voltage: $520-700$ voltage \\
& direct current (VDC) \\
\hline
\end{tabular}

The Gen I hybrid and CNG buses are the same model and age (model year 2002). Some of the differences between these two bus study groups are:

- $\quad$ CNG buses are taller (3 inches)

- Gen I hybrid buses are heavier (440 lbs)

- Gen I hybrid buses have a smaller engine (5.9 liter diesel versus a 8.5 liter natural gas)

- Gen I hybrid buses have a DPF; the CNG buses did not have additional emissions control

- Gen I hybrid buses have regenerative braking and CNG buses have a retarder

- Gen I hybrid buses have a smaller fuel capacity (100 gallons for hybrid and 125 gallons diesel equivalent for $\mathrm{CNG}$ )

There are several subtle differences between Gen II and Gen I hybrids. According to BAE Systems, four subsystems on Gen II have been improved, including the engine, generator, propulsion control, and cooling and packaging. The company expects these refinements to result in lower emissions; improved power; quieter operation; and improved reliability, durability, maintainability, and performance. Some of these differences are shaded and presented in Table 3. Details on the CNG and diesel buses are included for comparison. 
Table 3. Vehicle System Descriptions

\begin{tabular}{|c|c|c|c|c|}
\hline Bus Study Group & Gen II Hybrid & Gen I Hybrid & CNG & Diesel \\
\hline $\begin{array}{l}\text { Bus manufacturer and } \\
\text { model }\end{array}$ & $\begin{array}{l}\text { Orion VII, low } \\
\text { floor }\end{array}$ & $\begin{array}{l}\text { Orion VII, low } \\
\text { floor }\end{array}$ & $\begin{array}{c}\text { Orion VII, Low } \\
\text { Floor }\end{array}$ & $\begin{array}{l}\text { Orion V, High } \\
\text { Floor }\end{array}$ \\
\hline Model year & 2004 & 2002 & 2002 & 1994,1999 \\
\hline Length/width/height & $\begin{array}{l}40 \mathrm{ft} / 102 \\
\text { in./132 in. }\end{array}$ & $\begin{array}{l}40 \mathrm{ft} / 102 \\
\text { in./132 in. }\end{array}$ & $\begin{array}{l}40 \mathrm{ft} / 102 \\
\text { in/135 in }\end{array}$ & $\begin{array}{l}40 \mathrm{ft} / 102 \\
\text { in/121 in }\end{array}$ \\
\hline $\begin{array}{l}\text { Gross vehicle weight } \\
\text { rating (GVWR)/curb } \\
\text { weight }\end{array}$ & $\begin{array}{l}42,540 / 31,840 \\
\mathrm{lb}\end{array}$ & $\begin{array}{l}42,540 / 31,840 \\
\mathrm{lb}\end{array}$ & $\begin{array}{c}42,540 / 31,400 \\
\text { lbs }\end{array}$ & $\begin{array}{c}40,000 / 28,500 \\
\mathrm{lb}\end{array}$ \\
\hline Passenger capacity & $\begin{array}{l}38 \text { seated, } 32 \\
\text { standing }\end{array}$ & $\begin{array}{l}38 \text { seated, } 32 \\
\text { standing }\end{array}$ & $\begin{array}{l}37 \text { Seated, } \\
36 \text { Standing }\end{array}$ & $\begin{array}{l}39 \text { Seated, } \\
36 \text { Standing }\end{array}$ \\
\hline \multirow{2}{*}{$\begin{array}{l}\text { Engine manufacturer } \\
\text { and model }\end{array}$} & Cummins ISB & Cummins ISB & DDC S50G & DDC S50 \\
\hline & $\begin{array}{l}\text { (EGR } \\
\text { equipped) }\end{array}$ & $\begin{array}{l}\text { (not EGR } \\
\text { equipped) }\end{array}$ & $\begin{array}{l}\text { (not EGR } \\
\text { equipped) }\end{array}$ & $\begin{array}{l}\text { (not EGR } \\
\text { equipped) }\end{array}$ \\
\hline $\begin{array}{l}\text { Emission certification } \\
\text { level (g/bhp-hr) }\end{array}$ & $\begin{array}{l}\mathrm{NO}_{x} 2.5 \\
\mathrm{PM} 0.05\end{array}$ & $\begin{array}{l}\mathrm{NO}_{x} 4.0 \\
\mathrm{PM} 0.05\end{array}$ & & \\
\hline Rated horsepower & $\begin{array}{l}270 \text { bhp @ } \\
2,500 \text { rpm }\end{array}$ & $\begin{array}{l}270 \text { bhp @ } \\
2,500 \text { rpm }\end{array}$ & $\begin{array}{l}275 \text { bhp @ } \\
2,100 \text { rpm }\end{array}$ & $\begin{array}{l}275 \text { bhp @ } \\
2,100 \text { rpm }\end{array}$ \\
\hline Rated torque & $\begin{array}{l}660 \mathrm{lb}-\mathrm{ft} @ \\
1,600 \mathrm{rpm}\end{array}$ & $\begin{array}{l}660 \mathrm{lb}-\mathrm{ft} @ \\
1,600 \mathrm{rpm}\end{array}$ & $\begin{array}{c}900 \mathrm{lb}-\mathrm{ft} @ \\
1,200 \mathrm{rpm}\end{array}$ & $\begin{array}{c}890 \mathrm{lb}-\mathrm{ft} @ \\
1,200 \mathrm{rpm}\end{array}$ \\
\hline Emissions equipment & $\begin{array}{l}\text { Johnson } \\
\text { Matthey CRT }\end{array}$ & $\begin{array}{l}\text { Engelhard } \\
\text { DPX }\end{array}$ & None & $\begin{array}{l}\text { Retrofit DPF, } \\
\text { Johnson } \\
\text { Matthey }\end{array}$ \\
\hline DPF/HEV control & $\begin{array}{l}\text { Actively } \\
\text { managed }\end{array}$ & $\begin{array}{l}\text { Actively } \\
\text { managed }\end{array}$ & NA & NA \\
\hline Motor/controller cooling & $\begin{array}{l}\text { Oil/Oil } \\
\text { (integrated } \\
\text { system) }\end{array}$ & Oil/WEG & NA & NA \\
\hline $\begin{array}{l}\text { Retarder/regenerative } \\
\text { braking }\end{array}$ & $\begin{array}{l}\text { Regenerative } \\
\text { braking }\end{array}$ & $\begin{array}{l}\text { Regenerative } \\
\text { braking }\end{array}$ & Retarder & Retarder \\
\hline Generator mounting & $\begin{array}{l}\text { Direct mount } \\
\text { (no coupling) }\end{array}$ & Coupling & NA & NA \\
\hline Fuel capacity & $100 \mathrm{gal}$ & $100 \mathrm{gal}$ & $\begin{array}{l}125 \text { diesel } \\
\text { equivalent } \\
\text { gallons }\end{array}$ & 125 gallons \\
\hline Bus purchase cost $(\$)^{*}$ & 385,000 & 385,000 & $\$ 313,000$ & $\$ 290,000$ \\
\hline
\end{tabular}

\section{RESULTS}

IMPLEMENTATION EXPERIENCE - A CNG compression station was built at WF Depot to compress $6,600 \mathrm{scfm}$ of natural gas and fuel a bus in less than 5 minutes. Combustible gas detection was added to the maintenance area to accommodate the use of natural gas buses. The total cost of facility improvements at West Farms was $\$ 7.4$ million including the station, facility improvements, and $\$ 2$ million for blasting through solid rock to bury the high pressure gas lines. The hybrid buses required additional space at $\mathrm{MCH}$ and MTV for two battery conditioning stations $(\$ 70,000$ each, $\$ 140,000$ total) per depot. An overhead crane was also added to enable mechanics to service the battery tubs on top of the hybrid buses.

NYCT reported that the implementation of the CNG and both hybrid (Gen I and II) fleets went well, and the buses were quickly put into full service. NYCT, Orion, and BAE Systems reported that the buses performed as expected.
The bus operators reportedly like both hybrid and CNG buses, and cited their appreciation of the hybrid acceleration characteristics.

BUS USAGE - Table 4 presents the average monthly mileage per bus for the Gen II hybrids, Gen I hybrids and CNG buses (evaluation year 1). The overall 12-month average monthly miles per bus for the Gen II hybrids at MTV depot is about $10 \%$ lower than for the Gen I hybrids and CNG buses. This is primarily a function of depot size and routes served.

Table 4. Average Mileage per Month by Study Group

\begin{tabular}{|l|c|}
\hline \multicolumn{1}{|c|}{ Bus Group } & Average Miles per Month \\
\hline Gen II Hybrid & 2,134 \\
\hline Gen I Hybrid & 2,370 \\
\hline CNG & 2,295 \\
\hline
\end{tabular}

FUEL ECONOMY - The Gen I and Gen II hybrid fuel consumption and economy data are given in Table 5 and 
illustrated in Figure 2. Comparing evaluation year 1 in both cases, the 12-month average fuel economy for the Gen II hybrid buses is $5.9 \%$ lower than that of the Gen I hybrid buses $(p$-value $=0.002)$. There are several potential reasons for this difference in fuel economy. The Gen II and Gen I buses are equipped with CM850 and VP44 Cummins engine versions of the ISBH260 rating, respectively. The CM850 is equipped with EGR, while the VP44 is not. At governed speed and maximum power, a $1-2 \%$ increase in fuel consumption is expected with the CM850 EGR-equipped engine. An 8\% decrease in fuel consumption is expected at peak torque with the CM850 EGR-equipped engine. However, the engines are not operated at these three load points in this hybrid application - as noted above, engine loading has been optimized based upon dynamic torque speed characteristics of the engine. Cummins was unable to offer an expected increase in fuel consumption due to $E G R$, given the nature of the engine duty cycle in this hybrid application. In addition, BAE has updated both hardware and software from the Gen I to Gen II hybrid buses. Thus, the propulsion control system manages both the engine and the traction batteries differently for Gen II and Gen I buses.

The Gen I hybrid fuel economy increased nearly $1 \%$ from evaluation year 1 to evaluation year 2 . Although this difference is statistically insignificant ( $p$-value $=0.3$ ), it does indicate that lead-acid battery pack degradation is not occurring, insofar as the degradation affects overall in-use fuel economy. The section on traction batteries later in the report contains additional discussion.

Table 5. Gen II and Gen I Hybrid Bus Fuel Economy

\begin{tabular}{|l|c|c|c|c|}
\hline $\begin{array}{c}\text { Bus } \\
\text { Study } \\
\text { Group }\end{array}$ & $\begin{array}{c}\text { Evaluation } \\
\text { Year }\end{array}$ & $\begin{array}{c}\text { Mileage } \\
\text { (Fuel } \\
\text { Base) }\end{array}$ & $\begin{array}{c}\text { Diesel } \\
\text { Gallons } \\
\text { Consumed }\end{array}$ & $\begin{array}{c}\text { Miles } \\
\text { per } \\
\text { Gallon }\end{array}$ \\
\hline $\begin{array}{l}\text { Gen II } \\
\text { Hybrid }\end{array}$ & 1 & 246,926 & 82,213 & 3.00 \\
\hline $\begin{array}{l}\text { Gen I } \\
\text { Hybrid }\end{array}$ & 1 & 258,826 & 81,104 & 3.19 \\
\hline $\begin{array}{l}\text { Gen I } \\
\text { Hybrid }\end{array}$ & 2 & 263,130 & 81,677 & 3.22 \\
\hline CNG & 1 & 259,083 & $152,016^{*}$ & 1.70 \\
\hline Diesel & 1 & 436,672 & 187,157 & 2.33 \\
\hline
\end{tabular}

${ }^{*}$ Diesel gallon equivalents

Fuel economy of Gen I hybrids was measured previously using a chassis dynamometer [4]. Based upon the Manhattan drive cycle (average speed $6.8 \mathrm{mph}$ ), fuel economy was measured to be $4.79 \mathrm{mpg}$. The average speeds considered for this in-use evaluation (6.1 and 5.7 $\mathrm{mph}$ ) are slightly lower, which may contribute to lower fuel economy ( 3.19 and $3.22 \mathrm{mpg}$ ). In addition, the effect of air conditioning was not measured in chassis dynamometer testing.

Figure 2 shows average monthly fuel economy for the two hybrid study groups using available data for a 28month period. This span showcases the seasonal fluctuation in fuel economy experienced by both generations of hybrid buses. Note that these trends show fuel economy data prior to the evaluation period for the Gen II hybrids, and after the evaluation (evaluation year 2) of the Gen I hybrids. According to BAE Systems, much of this decrease is caused by an increase in energy consumption for air conditioning.

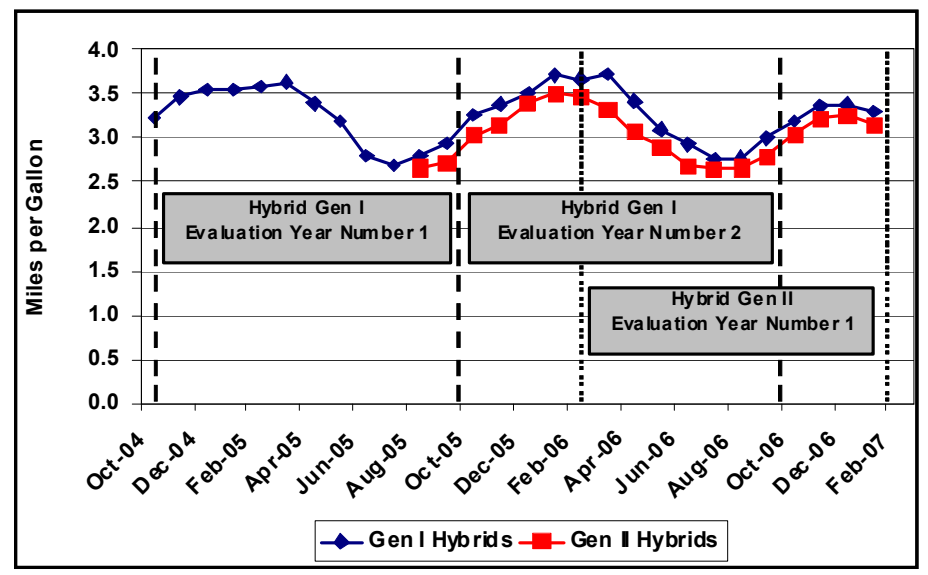

Figure 2. Average Fuel Economy, Hybrid Study Groups

Figure 3 shows average monthly fuel economy for the diesel, CNG and two hybrid study groups. Monthly fuel economy is presented in miles per diesel gallon, and adjusted for CNG buses by using the ratio of diesel and CNG energy contents. This comparison illustrates the seasonal fluctuation in fuel economy experienced by both generations of hybrid buses, which is not as pronounced in the diesel and CNG study groups. Although defining summer months can be subjective, if June through September are considered "summer" and the remaining eight months are "non-summer", there is a clear difference in seasonal fluctuation of fuel economy for the study groups. Hybrid Gen II, hybrid Gen I, CNG and diesel study groups had $15 \%, 18 \%, 1 \%$ and $4 \%$ decreases respectively, in fuel economy during these defined summer months. Air conditioning is a belt-driven accessory for all bus groups, and the same seasonal air conditioning load is experienced by diesel, CNG, and hybrid bus groups. While the diesel and CNG buses had conventionally sized engines for a 40-foot transit bus, the hybrids utilize a down-sized engine. Air conditioning load has a more pronounced effect on this smaller diesel powerplant. 


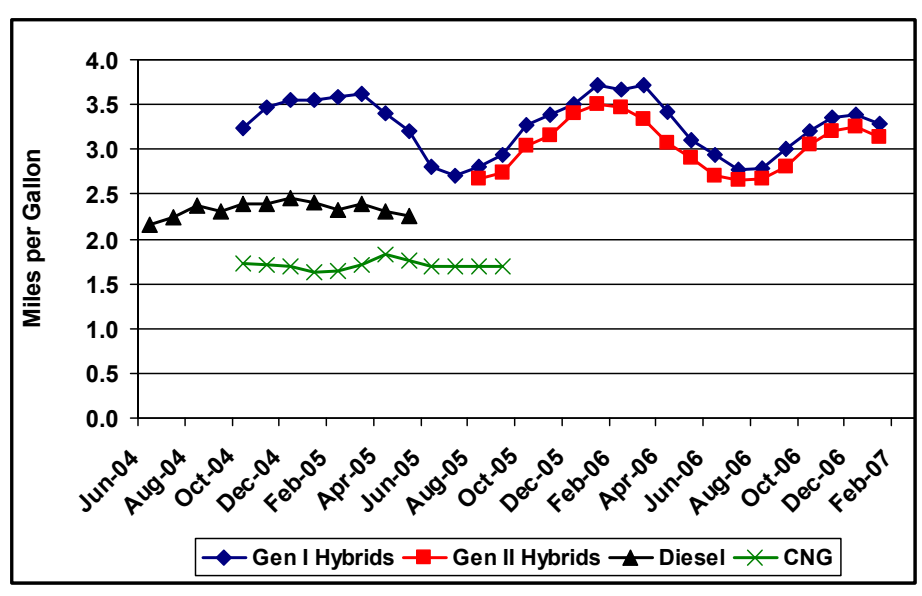

Figure 3: Average Fuel Economy, All Study Groups

MAINTENANCE COST ANALYSIS - The intent of this evaluation is to provide accurate actual capital and known operations costs associated with the hybrid and CNG vehicles for the time period selected. The diesel buses are older, and are therefore an inappropriate comparison due to their higher maintenance costs. This analysis is not predictive of maintenance costs assumed by the transit agency beyond the warranty period. The general warranty on these particular hybrids is two years from date of purchase, with some drivetrain components warranted beyond two years. The exact components and warranty periods, as negotiated by NYCT and Orion, are contractual.

The maintenance analysis in this section generally compares Gen II hybrids (evaluation year 1) to Gen I hybrids (evaluation year 1) and CNG buses (evaluation year 1). In evaluation year 1 , all buses were new enough that much of the maintenance was done under warranty by the manufacturers and their distributor mechanics. These warranty maintenance costs are not included in the maintenance cost analysis. Not accounting for warranty repairs in the evaluation of total maintenance cost offers an incomplete picture of true maintenance cost, however this analysis reflects the actual cost to the transit agency during the time period selected.

Total Maintenance Costs - This cost category includes the costs of parts and hourly labor costs of $\$ 50$ per hour, and does not include warranty costs. Cost per mile is calculated as follows:

Cost per mile $=\left(\left(\right.\right.$ labor hours $\left.{ }^{*} 50\right)+$ parts cost $) /$ mileage

The labor rate has been artificially set at a constant rate of $\$ 50$ per hour so that other analysts can change this rate to one more similar to their own. This rate does not directly reflect NYCT's current hourly mechanic rate.

Table 6 shows total maintenance costs for the Gen II and Gen I hybrids, and CNG buses. During evaluation year 1, the Gen II hybrids total maintenance cost per mile was $39 \%$ and $42 \%$ lower than for the Gen I hybrids and CNG buses, respectively. These differences are explored further in the breakdown of maintenance costs by vehicle system that follows Table 6.
Table 6. Total Maintenance Costs

\begin{tabular}{|l|c|c|c|c|c|}
\hline $\begin{array}{c}\text { Bus } \\
\text { Study } \\
\text { Group }\end{array}$ & $\begin{array}{c}\text { Evaluation } \\
\text { Year }\end{array}$ & $\begin{array}{c}\text { Miles } \\
\text { (Maint. } \\
\text { Base) }\end{array}$ & $\begin{array}{c}\text { Parts } \\
\mathbf{( \$ )}\end{array}$ & $\begin{array}{c}\text { Labor } \\
\text { Hours }\end{array}$ & $\begin{array}{c}\text { Cost } \\
\mathbf{( \$ / m i l e )}\end{array}$ \\
\hline $\begin{array}{l}\text { Gen II } \\
\text { Hybrid }\end{array}$ & 1 & 250,460 & 32,389 & 3,096 & 0.75 \\
\hline $\begin{array}{l}\text { Gen I } \\
\text { Hybrid }\end{array}$ & 1 & 285,349 & 61,408 & 5,793 & 1.23 \\
\hline $\begin{array}{l}\text { Gen I } \\
\text { Hybrid }\end{array}$ & 2 & 268,750 & 86,918 & 5,869 & 1.42 \\
\hline CNG & 1 & 275,444 & 99,980 & 5,133 & 1.29 \\
\hline
\end{tabular}

Propulsion-related Maintenance Costs - The propulsionrelated vehicle systems include the exhaust; fuel; engine; electric propulsion; nonlighting electrical (general electrical, charging, cranking, and ignition); air intake; cooling; and transmission systems. A traction battery discussion can be found later in this report.

Table 7 summarizes the cost comparisons among the study groups. Total propulsion-related systems maintenance costs per mile for the Gen II hybrid buses were $55 \%$ and $54 \%$ lower than the Gen I hybrid and CNG buses, respectively.

Table 7. Summary of Propulsion-Related Maintenance Costs

\begin{tabular}{|c|c|c|c|c|}
\hline $\begin{array}{l}\text { Vehicle } \\
\text { System }\end{array}$ & $\begin{array}{c}\text { Gen II } \\
\text { Hybrid } \\
\text { (\$/mile) }\end{array}$ & $\begin{array}{c}\text { Gen I } \\
\text { Hybrid } \\
\text { (\$/mile) }\end{array}$ & $\begin{array}{c}\text { Gen I } \\
\text { Hybrid } \\
\text { (\$/mile) }\end{array}$ & $\begin{array}{c}\text { CNG } \\
(\$ / \mathrm{mile})\end{array}$ \\
\hline $\begin{array}{l}\text { Evaluation } \\
\text { Year }\end{array}$ & 1 & 1 & 2 & 1 \\
\hline Exhaust & 0.0169 & 0.0241 & 0.0174 & 0.020 \\
\hline Fuel & 0.0176 & 0.0150 & 0.0150 & 0.058 \\
\hline Engine & 0.0331 & 0.0609 & 0.0367 & 0.064 \\
\hline $\begin{array}{l}\text { Electric } \\
\text { propulsion }\end{array}$ & 0.0387 & 0.1765 & 0.1266 & NA \\
\hline $\begin{array}{l}\text { Nonlighting } \\
\text { electrical }\end{array}$ & 0.0278 & 0.0416 & 0.0613 & 0.101 \\
\hline Air intake & 0.0087 & 0.0056 & 0.0054 & 0.012 \\
\hline Cooling & 0.0181 & 0.0309 & 0.0689 & 0.053 \\
\hline Transmission & 0.0008 & 0.0044 & 0.0039 & 0.036 \\
\hline Total & 0.162 & 0.359 & 0.335 & 0.349 \\
\hline
\end{tabular}

The lower Gen II hybrid maintenance costs are likely due to the improvements made from Gen I to Gen II. However, an additional component may be that the NYCT mechanics became more familiar with maintaining the BAE system over time.

TRACTION BATTERIES - The lead-acid traction batteries used by BAE Systems are characterized by a 3year life expectancy and the need for conditioning at 6month intervals. Depots that operate hybrids are equipped with two battery conditioners, which have a per unit cost of approximately $\$ 70,000$. NYCT personnel schedule traction battery conditioning as part of the preventive maintenance. 
During the evaluation period (February 2006 through January 2007), the Gen II hybrid study bus group had zero battery failures. In the months prior to the evaluation period, there were 13 single battery failures, which are assumed to be related to quality control issues.

The Gen I hybrids experienced a $4.8 \%$ failure rate per year during evaluation year 1 , and a $3.3 \%$ failure rate per year during evaluation year 2. In April 2006, BAE Systems released a software change for the hybrid propulsion system to make identifying faulty batteries less aggressive and to reduce the overall number of traction batteries removed with no true failure. This software change was applied just past the midpoint of Gen I evaluation year 2 (October 2005 through September 2006), and may have lowered the apparent failure rate during that time.

The Gen I hybrid traction batteries are at their 3-year life expectancy. Given the lack of fuel economy degradation from evaluation year 1 to evaluation year 2 , it appears that in this application, the traction battery technology is capable of reaching its projected life expectancy without decreased performance.

REGENERATIVE BRAKING - The brake system maintenance costs are expected to be lower for hybrid propulsion systems with regenerative braking. Regenerative braking allows the electric drive motors to slow down a bus, similar to a transmission retarder. On Orion/BAE hybrid buses, energy from braking is taken at the rear (drive) axle into the electric drive motor, and then fed back to the traction batteries. NYCT does not use the maximum available regenerative braking capacity, preferring for safety reasons that nonhybrid and hybrid buses have a similar feel to drivers when they release the accelerator. The transit bus application generally utilizes rear brakes more than the front brakes, thus a brake reline is commonly performed on rear brakes first. While the "2-wheel reline" is the most common first reline activity, the "4-wheel reline" is also occasionally observed.

In this comparison of brake maintenance, Gen I hybrids are compared to CNG buses on miles to first brake reline. The first brake reline for both groups occurred during evaluation year number 2. Gen II hybrids have not yet accumulated sufficient mileage to make this comparison. CNG buses serve as the baseline (nonhybrid) in this comparison. NYCT expects nonhybrid buses to have a four-wheel brake reline every 18,000 miles on average.

Additional issues contributing to this comparison are

- The hybrids weigh 440 pounds more than the CNG buses.

- The brake assembly and pad materials are the same for each group.

- The majority of braking is naturally applied to the rear wheels, which is compounded by regenerative braking at the electric drive motor coupled to the rear (drive) axle.

There is parity between hybrid and CNG buses in brake materials, and the hybrids have a weight disadvantage that should nominally contribute to a slight increase in brake wear. The focus of regenerative braking at the rear wheels will theoretically extend the two-wheel reline period, as well as the four-wheel reline period. Table 8 shows that the Gen I hybrid buses accumulated more than two times the mileage of the CNG buses before requiring their first brake reline. This $\sim 2 x$ trend is also true when comparing first 2-wheel relines or first 4-wheel relines between groups.

Table 8. Brake Reline Comparison

\begin{tabular}{|l|l|l|l|}
\hline $\begin{array}{c}\text { Bus } \\
\text { Number }\end{array}$ & \multicolumn{1}{|c|}{ Date } & \multicolumn{1}{c|}{$\begin{array}{c}\text { Reline } \\
\text { Type }\end{array}$} & $\begin{array}{c}\text { Odometer } \\
\text { Reading }\end{array}$ \\
\hline \multicolumn{4}{|c|}{ Hybrid Buses } \\
\hline 6367 & $02 / 21 / 2006$ & 4-wheel & 50,807 \\
\hline 6368 & $07 / 25 / 2006$ & 2-wheel & 66,455 \\
\hline 6368 & $12 / 28 / 2006$ & 2-wheel & 74,523 \\
\hline 6369 & $05 / 04 / 2005$ & 2-wheel & 57,073 \\
\hline 6375 & $04 / 11 / 2006$ & 4-wheel & 54,685 \\
\hline 6378 & $09 / 26 / 2006$ & 4-wheel & 68,444 \\
\hline 6379 & $03 / 13 / 2006$ & 4-wheel & 49,272 \\
\hline 6380 & $01 / 26 / 2006$ & 2-wheel & 48,685 \\
\hline 6381 & $02 / 28 / 2006$ & 4-wheel & 50,267 \\
\hline 6382 & $11 / 02 / 2005$ & 4-wheel & 45,217 \\
\hline 6387 & $07 / 07 / 2006$ & 4-wheel & 59,769 \\
\hline \multicolumn{5}{|c|}{ CNG Buses } \\
\hline \multicolumn{5}{|c|}{ Average } & First reline & 55,067 \\
\hline 7657 & $07 / 08 / 2004$ & $4-w h e e l$ & 20,288 \\
\hline 7662 & $09 / 22 / 2004$ & 2-wheel & 20,043 \\
\hline 7666 & $01 / 01 / 2005$ & 4-wheel & 28,759 \\
\hline 7670 & $10 / 08 / 2004$ & 2-wheel & 25,924 \\
\hline 7677 & $01 / 14 / 2005$ & 2-wheel & 24,730 \\
\hline 7688 & $06 / 22 / 2005$ & 4-wheel & 33,581 \\
\hline \multicolumn{5}{|c|}{ Average } & First reline & 25,554 \\
\hline
\end{tabular}

RELIABILITY - Miles between roadcalls (MBRC) is an important reliability metric in the transit industry. Table 9 shows the cumulative average overall MBRC, as well as the propulsion system MBRC metric. NYCT's expectation is that all buses should meet or exceed 4,000 total MBRC. The Gen I and Gen II hybrids and CNG buses all exceed this expectation.

Table 9. Cumulative MBRC Comparison

\begin{tabular}{|l|l|l|l|l|}
\hline \multicolumn{1}{|c|}{$\begin{array}{c}\text { Study } \\
\text { Group }\end{array}$} & $\begin{array}{c}\text { Gen II } \\
\text { Hybrid }\end{array}$ & $\begin{array}{c}\text { Gen I } \\
\text { Hybrid }\end{array}$ & $\begin{array}{c}\text { Gen I } \\
\text { Hybrid }\end{array}$ & CNG \\
\hline $\begin{array}{l}\text { Evaluation } \\
\text { Year }\end{array}$ & 1 & 1 & 2 & 1 \\
\hline Total MBRC & 5,445 & 5,188 & 6,250 & 5,738 \\
\hline $\begin{array}{l}\text { Propulsion } \\
\text { MBRC }\end{array}$ & 8,678 & 8,153 & 8,669 & 8,885 \\
\hline
\end{tabular}


SUMMARY OF COSTS - Table 10 summarizes fuel and maintenance costs per mile for the Gen II and Gen I hybrid study groups. The total operating cost per mile for the Gen II hybrid buses is $24 \%$ and $39 \%$ lower than the Gen I hybrids and CNG buses during each respective evaluation year 1 . The discrepancy with Gen I hybrids is driven by the $39 \%$ lower maintenance costs in operating the Gen II hybrids. The discrepancy with CNG buses is driven by both fuel and maintenance costs.

Table 10. Summary of Operating Cost per Mile

\begin{tabular}{|l|c|c|c|c|}
\hline $\begin{array}{l}\text { Study } \\
\text { Group }\end{array}$ & $\begin{array}{c}\text { Evaluation } \\
\text { Year }\end{array}$ & $\begin{array}{c}\text { Fuel } \\
\text { \$/Mile }\end{array}$ & $\begin{array}{c}\text { Maintenance } \\
\text { \$/Mile }\end{array}$ & $\begin{array}{c}\text { Total } \\
\text { \$/Mile }\end{array}$ \\
\hline $\begin{array}{l}\text { Gen II } \\
\text { Hybrid }\end{array}$ & 1 & 0.66 & 0.75 & 1.41 \\
\hline $\begin{array}{l}\text { Gen I } \\
\text { Hybrid }\end{array}$ & 1 & 0.62 & 1.23 & 1.85 \\
\hline $\begin{array}{l}\text { Gen I } \\
\text { Hybrid }\end{array}$ & 2 & 0.62 & 1.42 & 2.04 \\
\hline CNG & 1 & 1.02 & 1.29 & 2.31 \\
\hline
\end{tabular}

\section{CONCLUSION}

The primary conclusions from this study are:

- With similar usage and duty cycle, the Gen II hybrids exhibited a $5.9 \%$ lower fuel economy than the Gen I hybrids. This is likely due to the MY2004 EGR-equipped engine in the Gen II hybrids, as well as differences in hardware and software related to propulsion control in the Gen II buses. The Gen II hybrids also exhibited $43 \%$ and $22 \%$ better fuel economy than the CNG and diesel buses, respectively.

- The Gen I hybrid fuel economy was statistically the same over two years of evaluation up through year number three of service. This indicates that the lead-acid battery chemistry is capable of consistent performance in this duty cycle application, through the projected three year lifespan.

- The total maintenance costs for the Gen II hybrids were $39 \%$ and $42 \%$ lower than the Gen I hybrids and CNG buses for each respective evaluation year number 1 .

- The propulsion-related maintenance costs for the Gen II hybrids were $55 \%$ and $54 \%$ lower than the Gen I hybrids and CNG buses for each respective evaluation year number 1 .

- The Gen I hybrid buses accumulated more than two times the mileage of the CNG buses before requiring their first brake reline. For NYCT, this indicates tangible advantage to regenerative braking in terms of lower brake system maintenance costs related to brake relines. However, it should be noted that brake wear is a function of duty cycle, driver behavior, and transmission retarder type and tuning.

- The Gen II hybrids exhibited similar reliability (as measured in MBRCs) to the Gen I hybrids and
CNG buses. All three study groups exceeded NYCT's expectations in this arena.

- Due to lower maintenance costs, but despite worsened fuel economy, the Gen II hybrids total operating cost per mile was $24 \%$ lower than the Gen I hybrids for each respective evaluation year I. The Gen II hybrids exhibited a 39\% lower total operating cost per mile than the CNG buses in each respective evaluation year 1 .

\section{ACKNOWLEDGMENTS}

The FreedomCAR and Vehicle Technologies Program, Advanced Vehicle Testing Activity Subprogram of the U.S. Department of Energy sponsored NREL's work on this project.

Additionally, the author wishes to thank Steve Tilyou and Tom Webb at BAE Systems, and Shawn Whitacre at Cummins.

\section{REFERENCES}

1. Barnitt, R. (2007). BAE/Orion Hybrid Electric Buses at New York City Transit, A Generational Comparison. NREL/TP-540-42217. Golden, CO: National Renewable Energy Laboratory (NREL).

2. Barnitt, R.; Chandler, K. (2006). New York City Transit (NYCT) Hybrid and CNG Transit Buses: Final Evaluation Results. NREL/TP-540-40125. Golden, CO: National Renewable Energy Laboratory (NREL).

3. Chandler, K.; Walkowicz, K.; Eudy, L. (2002). New York City Transit Diesel Hybrid-Electric Buses: Final Results. NREL/BR-540-32427. Golden, CO: NREL.

4. Environment Canada. (2004). Orion VII Transit Bus Equipped with BAE Systems HybriDrive Propulsion System Emissions and Fuel Economy Test Report. ERMD Report \#2004-18. Ottawa, Ontario: Environment Canada.

\section{CONTACT}

Robb Barnitt can be contacted at robb barnitt@nrel.gov.

\section{DEFINITIONS, ACRONYMS, ABBREVIATIONS}

AC: alternating current

AVTA: Advanced Vehicle Testing Activity

bhp: brake horsepower

CNG: compressed natural gas

CO: carbon monoxide

CRT: continuously regenerating technology

DDC: Detroit Diesel Corporation

DOE: U.S. Department of Energy

DPF: diesel particulate filter

EGR: exhaust gas recirculation

EPA: U.S. Environmental Protection Agency 
ERMD: Emissions Research \& Measurement Division (Environment Canada)

Gal: gallons

g/bhp-hr: grams per brake horsepower hour

GVWR: gross vehicle weight rating

HC: hydrocarbons

HEV: hybrid electric vehicle

hp: horsepower

lb-ft: pound-foot

MBRC: miles between roadcalls

MCH: Mother Clara Hale Depot

MIDAS: Maintenance Information Diagnostic Analysis

System

mpg: miles per gallon

mph: miles per hour

MTA: Metropolitan Transportation Authority

MTV: Manhattanville Depot

NiMH: nickel metal hydride

NMHC: nonmethane hydrocarbons

$\mathrm{NO}_{\mathrm{x}}$ : oxides of nitrogen

NREL: National Renewable Energy Laboratory

NYCT: New York City Transit

PM: particulate matter

PMI: preventive maintenance inspection

ppm: parts per million

PTI: Pennsylvania Transportation Institute

RC: roadcall

rpm: revolutions per minute

scfm: standard cubic feet per minute

SOC: state of charge

ULSD: Ultra Low Sulfur Diesel

VDC: voltage direct current

WEG: Water Ethylene Glycol

WF: West Farms Depot 